\title{
Amyotrofik Lateral Skleroz (ALS) hastalığının patogenezi
}

\author{
Pathogenesis of amyotrophic lateral sclerosis (ALS)
}

Ahmet Doğucem Marangoz, Çağdaş Erdoğan

\section{Özet}

İlk olarak on dokuzuncu yüzyılda Charcot tarafından tanımlanan Amyotrofik Lateral Skleroz (ALS), genellikle üç ile beş yıllık bir sağkalım ile seyreden, sürekli ilerleyici bir nörodejeneratif hastalıktır. Motor nöronlarda dejenerasyon ve ölüm ile karakterize olup, kortikal motor hücreler (piramidal ve Betz hücreleri), kortikospinal trakt, ve ön boynuz hücrelerinde belirgin aksonal kayıp görülür. ALS'nin etiyolojisi tam olarak bilinmemekle birlikte, patogenezinde pek çok farklı etmenin rol oynadığı ileri sürülmektedir. Genetik, oksidatif stres, glutamat eksitotoksisitesi, mitokondrial disfonksiyon, aksonal transport bozukluğu, nöroinflamasyon, RNA bozuklukları bunlardan başlıcalarıdır. Yine nörotrofik faktörler, organeller arası trafiğin bozulması, sinyal yolaklarında bozukluk, metabolik değişiklikler gibi faktörlerin de süreçte rol oynadığı düşünülmektedir. Bu derlemede ALS hastalığının patogenezi gözden geçirilmiştir.

Anahtar kelimeler: Amyotrofik lateral skleroz, patogenez, etiyoloji, genetik, mitokondrial bozukluk.

MarangozAD, Erdoğan Ç. Amyotrofik Lateral Skleroz (ALS) hastalığının patogenezi. Pam Tıp Derg 2020;13:477484.

\begin{abstract}
Amyotrophic Lateral Sclerosis (ALS), first described by Charcot in the nineteenth century, is a progressive neurodegenerative disease, usually with a three to five-year survival. ALS is characterized by degeneration and death in motor neurons. Cortical motor cells (pyramidal and Betz cells), corticospinal tract and anterior horn cells show prominent axonal loss. Although the etiology of ALS is not known exactly, it is suggested that many different factors play a role in its pathogenesis. Genetics, oxidative stress, glutamate excitotoxicity, mitochondrial dysfunction, axonal transport disorder, neuroinflammation, RNA disorders are the main ones. Factors such as neurotrophic factors, impaired intercellular traffic, disturbance of signaling pathways and metabolic changes are thought to play a role in the process. In this article, pathogenesis of ALS disease is reviewed.
\end{abstract}

Key words: Amyotrophic lateral sclerosis, pathogenesis, etiology, genetic, mitochondrial dysfunction.

Marangoz AD, Erdoğan Ç. Pathogenesis of amyotrophic lateral sclerosis (ALS). Pam Med J 2020;13:477-484.

\section{Giriş}

Illk olarak on dokuzuncu yüzyılda Charcot tarafından tanımlanan Amyotrofik Lateral Skleroz (ALS), genellikle üç ile beş yıllık bir sağkalım ile seyreden, sürekli ilerleyici bir nörodejeneratif hastalıktır. Motor nöronlarda dejenerasyon ve ölüm ile karakterize olup, kortikal motor hücreler (piramidal ve Betz hücreleri), kortikospinal trakt, ve ön boynuz hücrelerinde belirgin aksonal kayıp görülür. ALS'nin etiolojisi tam olarak bilinmemekle birlikte, patogenezinde pek çok farklı etmenin rol oynadığı ileri sürülmektedir. Genetik, oksidatif stres, glutamat eksitotoksisitesi, mitokondrial disfonksiyon, aksonal transport bozukluğu, nöroinflamasyon, RNA bozuklukları bunlardan başlıcalarıdır. Yine nörotrofik faktörler, organeller arası trafiğin bozulması, sinyal yolaklarında bozukluk, metabolik değişiklikler gibi faktörlerin de süreçte rol oynadığı düşünülmektedir. Son yıllarda yapılan çalışmalar otofaji yolaklarındaki disfonksiyonun da ALS patogenezinde önemli rol oynadığını göstermektedir.

\section{Genetik}

Tüm ALS vakalarının yaklaşık 10'unu ailesel ALS vakaları oluşturur ve fenotipik ve genetik olarak heterojendir [1]. Genellikle OD kalıtım gösterir. SOD-1 mutasyonu ile olan ilişkisi ilk

Ahmet Doğucem Marangoz, Arş. Gör. Dr. Pamukkale Üniversitesi Tıp Fakültesi Nöroloji Anabilim Dalı, Denizli, Türkiye, e-posta: dogucemm@ gmail.com (orcid.org/0000-0001-7647-3435) (Sorumlu Yazar)

Çağdaş Erdoğan, Doç. Dr. Pamukkale Üniversitesi Tıp Fakültesi Nöroloji Anabilim Dalı, Denizli, Türkiye, e-posta: drcagdaserdogan@gmail.com (orcid.org/0000-0002-6231-7834) 
kez 1993 yılında ileri sürülmüştür. Sonraki gelişmeler bazı genlerin ALS'ye neden olduğunu (Tablo 1) bazılarının ise ALS riskini arttırdığını ya da hastalık sürecini etkileyebildiğini (Tablo 2) göstermiştir.

Tablo 1. ALS' ye yol açan genler.

\begin{tabular}{llll}
\hline Gen & Fonksiyonu & Klinik Fenotip & Epidemiyoloji \\
\hline ALS2 & Hücresel transport & j-ALS, j-PLS, HSP & $<\% 1$ fALS \\
ANG & RNA metabolizması & ALS, PD & $<\% 1$ ALS \\
C9ORF72 & RNA metabolizması & ALS, FTD & $\% 40$ fALS, \%5-6 sALS \\
CHMP2B & Hücresel transport & ALS, FTD & Bilinmiyor \\
DAO & Glutamaterjik & ALS & $<\% 1$ fALS \\
FUS & DNA/RNA metabolizması & ALS, j-ALS, FTD & $\% 5$ fALS, $\% 1$ sALS \\
hnRNPA1 & RNA metabolizması & ALS, FTD, IBMPFD & Bilinmiyor \\
hnRNPA2B1 & RNA metabolizması & ALS, FTD, IBMPFD & Bilinmiyor \\
OPTN & Protein metabolizması & ALS & $<\% 1$ fALS \\
RFN1 & Aksonal büyüme & ALS & $<\% 1$ fALS \\
SETX & DNA/RNA metabolizması & j-ALS & $<\% 1$ fALS \\
SOD1 & Oksidatif hasarı önlemek & ALS, FTD, PMA & $\% 20$ fALS, \%3 sALS \\
SPG11 & Nöronal maturasyon & j-ALS, HSP & Bilinmiyor \\
SQSTM1 & Protein metabolizması & ALS, FTD & $<\% 2$ ALs \\
TAF15 & RNA metabolizması & ALS & Bilinmiyor \\
TATDBP & DNA/RNA metabolizması & ALS, FTD & $\% 3$ fALS, \%2 sALS \\
UBQLN2 & Protein metabolizması & ALS, FTD & $<\% 2$ fALS \\
VAPB & Hücresel transport & ALS, PMA & $<1$ fALS \\
VCP & Protein metabolizması & ALS, FTD, IBMPFD & $\% 1-2$ fALS \\
\hline
\end{tabular}

ALS, amyotrofik lateral skleroz; fALS, familyal ALS; FTD, frontotemporal demans; HSP, herediter spastik parapleji; IBMPFD, inklüzyon cisimcikli miyozit, Paget Hastalığı ve frontotemporal demans; j, jüvenil; PD, Parkinson Hastalığı; PLS, primer lateral skleroz; PMA, progresif muskuler atrofi; sALS, sporadik ALS

Tablo 2. ALS riskini arttıran genler.

\begin{tabular}{lll}
\hline Gen & Protein & Moleküler \\
\hline ALS2 & Ataxin-2 & RNA metabolizması \\
CHGB & Chromogranin B & Protein metabolizması \\
CREST & nBAF, SS18L1 & DNA regülasyonu \\
ELP3 & Elongator Protein 3 & Aksonal Büyüme \\
EPHA4 & Ephrin A4 & Aksonal Büyüme \\
FIG4 & Polifosfoinozitid fosfataz & Lipid metabolizması \\
GRN & Progranulin & Büyüme faktörü \\
HFE & İnsan hemokromatozis protein & Demir metabolizması \\
KIFAP3 & Kinesin-ilişkili protein 3 & Hücresel transport \\
NEFH & Nöroflament ağır zincir & Hücre iskeleti \\
UNC13A & UNC13A protein & Nörotransmisyon \\
VEGF & Vasküler endoltelyal büyüme faktörü & Angiogenez \\
\hline
\end{tabular}


Süperoksit dismutaz tip 1 (SOD-1) mutasyonu familyal ALS'lerin \%20'sinde, sporadik ALS'lerin ise \%2'sinde gözlenmektedir. SOD1 genindeki mutasyonların bazı ailesel ALS vakalarıyla ilişkili olduğunun keşfi, serbest radikal toksisitesinin ALS patogenezinde rol oynayabileceğini düşündürmüştür; çünkü SOD1 proteini, toksik süperoksit radikallerinin, oksijene $(\mathrm{O} 2)$ ve hidrojen peroksite $(\mathrm{H} 2 \mathrm{O} 2)$ dönüşümünü katalize eden bir metalloenzimdir [2]. Genel olarak SOD1 mutasyonunun, proteinin antioksidan işlevini kaybetmesine yol açarak ALS'ye neden olduğu düşünülse de, SOD1 knockout farelerde motor nöron hastalığının gelişmediğini gösteren çalışmalar mevcuttur [3]. Yine SOD1 geninde ALS'ye neden olabilen 180'den fazla mutasyon tespit edilmiş olup, bunların çoğunda enzim aktivitesi kısmen de olsa korunmuştur. Dolayısıyla fonksiyon kaybı dışı süreçler de patogenezde rol oynuyor görünmektedir.

Toksik fonksiyon kazanımı hipotezi bunlardan birisidir [4]. SOD1 proteini, antioksidan aktivitenin yanı sıra pro-oksidan aktivite de içerir. Mutant SOD1'in transjenik farelerde ve insan hücre dizilerinde NADPH oksidazı (Nox) doğrudan uyardığını ve dolayısıyla serbest radikal temizleme görevi bulunduğunu gösteren çalışmaların aksine reaktif oksijen radikallerinin aşırı üretilmesine neden olduğunu gösteren kanıtlar da vardır [5].

Bir başka hipotez, mutant SOD1'in motor nöronlar için potansiyel olarak toksik protein agregatlarını indüklemesidir [6]. ALS'de, mutant SOD1 proteininin disülfit çapraz bağlı agregatlarının birikimi gösterilmiştir. Ancak bunun ALS'nin patogenezinde bir primer olay mı yoksa hastalığın ileri evrelerinde ortaya çıkan ikincil bir durum mu olduğu net değildir.

Kromozom 9p21 üzerindeki C9ORF72 genindeki uzamış tekrar dizileri, klasik ALS, frontotemporal demans (FTD) ve FTD-ALS ile bağlantılıdır. Bu uzamış tekrar dizilerinin, ailesel ALS'nin en yaygın nedenlerinden biri olduğu görülmektedir. Bu durum, Avrupa popülasyonlarındaki vakaların yaklaşık \%34'ünü ve Asya popülasyonlarındaki vakaların \%2'sini oluşturmaktadır [7]. Ek olarak, Avrupa popülasyonlarında sporadik ALS vakalarının yaklaşık yüzde 5'inde C9ORF72 uzamış tekrar dizileri gözlenmiştir.
C9ORF72 genindeki mutasyon fALS'nin en sık nedenidir. Bu gen, türler arasında yüksek oranda korunan, tam olarak karakteristiği belirlenememiş bir proteini kodlar. Normalde 24'ten az olması gereken heksanükleotid tekrar dizleri, FTD-ALS vakalarında 2501600 tekrar arasında değişmektedir [8]. $\mathrm{Bu}$ mutasyonun nasıl hastalığa yol açtığı net değildir. Heksanükleotid tekrarları 'G-quadruplex' olarak adlandırılan ikincil bir yapı oluşturmak üzere katlanabilen guaninden zengin sekanslardan (GGGGCC) oluşur [9]. Bir hipotez, heksanükleotid tekrar dizisinin ve G-quadruplex formasyonunun, patolojik moleküler değişikliklere yol açan bir kaskadı başlattığı yönündedir. Bunun sonucunda RNA / DNA hibritlerinin ve kusurlu RNA transkriptlerinin oluştuğu ve tam uzunluktaki RNA transkriptlerinin üretiminin azaldığı düşünülmektedir. Kusurlu RNA transkriptleri, nükleolus dahil olmak üzere bir dizi ribonükleoproteinlere bağlanır. $\mathrm{Bu}$ durum, nükleolus içindeki esansiyel bir proteinin yanlış bir şekilde konumlanmasına ve hücre canlıı̆̆ının azalmasına yol açar [10].

Bir başka hipotez uzamış tekrar dizileri içerisinde, tekrar ilişkili non-ATG translasyonun (RAN translasyonu) ortaya çıkmasıdır. Bu durum RNA işleminin çeşitli aşamalarına dahil olan, agregasyona yatkın toksik dipeptid tekrar (DPR) proteinlerinin üretilmesine yol açar. Bu proteinler sitoplazmada toksik aggregatlar oluşturur ve ayrıca aksonal transportu bozar [11]. Bir diğer hipotez ise uzamış tekrar dizilerinin, C9orf72 protein düzeylerinin azalmasına neden olarak, gerek RNA süreçlerine gerek mikroglial yanıtın etkilenmesine yol açmasıdır [12].

TAR DNA bağlayıcı protein 43 (TDP-43)'ü kodlayan 1p36.22 kromozomundaki TARDBP genindeki mutasyonlar otozomal dominant ailesel ALS'nin bir diğer nedenidir [13]. Bu mutasyonlar, Avrupa populasyonlarında ailesel ALS vakalarının yaklaşık yüzde 4'ünü ve Asya populasyonlarında ailesel ALS vakalarının yüzde 2'sini oluşturmaktadır. Sporadik ALS vakalarının ise \%1'ini oluşturmaktadır [7]. Kendisi ALS'nin nadir bir nedeni olsa da TDP43'ün ALS'lilerin çoğunda görülen ubikitin inklüzyonlarının önemli bir bileşeni olduğu tespit edilmiştir.

16. kromozom üzerindeki 'fused in sarcoma' (FUS) genindeki mutasyonlar, çeşitli etnik 
gruplardan çeşitli ailelerde ailesel ALS'yle ilişkilendirilmiştir. Gerek FUS gerek TARDBP, normalde, transkripsiyon regülasyonu, RNA splicing ve RNA transportunda da görev almaları nedeniyle nükleusta bulunurlar. ALS'de fonksiyonlarındaki azalma ve değişimler sonucu RNA işlem sürecinin farklı basamaklarının etkilendiğini ve bu şekilde ALS'ye neden olduklarını düşündüren bulgular vardır. Yine ALS'de bu proteinlerin sitoplazmaya doğru yer değiştirdikleri ve orada toksik agregatlar oluşturarak da patogenezde rol oynadıkları düşünülmektedir [14].

Yukarıda bahsedilen genetik olarak etkinliği görece olarak daha fazla ilişkilendirilmiş genlerin dışında ALS etyopatogenezinde üzerinde durulan çok daha fazla sayıda OD, OR ve Xe bağlı dominant kalıtılan gen bulunmaktadır. (SETX, VAPB, ANG, FIG4, OPTN, VCP, PFN1 gibi) Ancak unutulmamalıdır ki ALS \%10 oranında ailesel olarak görülmekle birlikte, \%90 oranında sporadik olarak ortaya çıkmaktadır. Bu durum genetik sebepler dışında etyopatogenezde farklı çevresel etmenlerin de olduğunu ve farklı mekanizmaların patogenezde rol oynadığını düşündürmektedir

\section{Oksidatif stres}

Yukarıda da bahsedildiği gibi SOD1 mutasyonlarının ALS'ye neden olabildiğinin gösterilmesi oksidatif stresin ALS patogenezinde rol oynadığı fikrini desteklemektedir. Postmortem çalışmalarda da ALS'de oksidatif stresin rol oynadığını düşündürür bulgular elde edilmiştir. Yine normalde sitoplazmada bulunan, oksidatif stres durumunda çekirdeğe geçerek antioksidan görev yapan Nrf-2'nin de ALS'de azaldığı gösterilmiştir [15].

\section{Glutamat eksisitotoksisitesi}

Presinaptik uyarı glutamat ile postinaptik alana taşınır. NMDA ve AMPA gibi reseptörlerini uyararak kalsiyumun hücreye girişi sağlanır. Sinaptik aralıktaki glutamat eksitatör aminoasit transporter (EATT) sistemleri ile uzaklaştırılır. Glutamat reseptörlerinin aşırı aktivasyonu, kalsiyumun hücrelere daha fazla girişine yol açabilir. Hücre içi kalsiyum artışı sırasıyla, lipid peroksidasyonu, nükleik asit hasarı ve mitokondriyal bozulma yoluyla nöronal hücre ölümüne neden olan bir olay zincirini tetikleyebilir.
ALS'li hastaların beyin omurilik sıvısında artmış glutamat düzeylerinin hastalık şiddeti ile ilişkili olduğu, ve bu BOS örneklerinin hücre kültürlerinde neden olduğu toksisitenin glutamat antagonistleri ile önlenebileceği gösterilmiştir. EAAT-2 düzeyinin ALS'de düşük olabileceği yada non-fonksiyonel formunun ALS'li dokularda öne çıkabileceğini öne sürülmüştür [16].

Glutamat reseptör disfonksiyonu eksitotoksisite hipotezini destekleyen başka bir potansiyel mekanizmadır. ALS'li hastaların spinal motor nöronlarında, bir glutamat AMPA reseptör subüniti olan GLUR2'yi kodlayan mesajcı RNA'da hatalı işlenme olduğu tespit edilmiştir. $\mathrm{Bu}$ hatalı işlenme, defektif AMPA reseptör alt tipi aracılığıyla kalsiyum iyonlarına artan geçirgenliğe sebep olabilir ve nöronal ölüme yol açan bir dizi olayı tetikleyebilir [17].

\section{Mitokondriyal disfonksiyon}

Mitokondriler ATP sentezlenirken solunum zincirinde bazı elektronlar normalden sapar ve ROS oluşur. Bunlar SOD gibi çeşitli sistemler ile temizlenir. Kalsiyum artarsa oksidatif fosforilasyon ve ATP sentezi ve buna bağlı olarak ROS üretimi de artar. Dolayısıyla artmış kalsiyum ya hücre dışına pompalanır ya da depolanarak tamponlanır. Bu depolama mitokondri kapasitesini aşarsa mitokondrinin iç membranları arası potansiyel farkı kaybolur ve ATP sentezi durur [18].

Transgenik mutant SOD1 fare modelinde, mitokondrial disfonksiyonun, motor nöron hasarının diğer bulgularından önce hastalığın çok daha erken evrelerinde ortaya çıktığı gösterilmiştir. ALS'de mitokondrilerde şişme ve vakuolizasyon saptanır. TDP-43'ün solunum zinciri kompleksini etkileyebildiği, C9ORF72'nin de mitokondriyal disfonksiyona yol açabildiği gösterilmiştir [19].

\section{Aksonal transport}

Hasarlı motor nöronlar içinde bulunan hücre içi nörofilament inklüzyonları, ALS patogenezinde üzerinde durulan bir diğer mekanizmadır. Nörofilamentler, motor nöronlar tarafından yüksek seviyelerde eksprese edilen bir ara filament türüdür. Normalde hücre şeklini sürdürmede ve aksonal transportta hayati roller üstlenen yapısal elemanlar olarak işlev görürler. Bozulmuş nörofilamentler aksonal transportu bozabilir ve aksonal strangülasyona 
neden olabilir [20]. ALS'nin sporadik ve ailesel formlarında, nörofilament ağır subünitinde mutasyonlar olduğu gösterilmiştir. ALS hastalarının spinal motor nöronlarında hafif subünit mRNA düzeylerinde de azalma saptanmıştır. Transgenik farelerde, nörofilament subünitlerinin aşırı ekspresyonu veya delesyonunun, ALS hastalarında görülenlere benzer şekilde motor nöron dejenerasyonu ve aksonal şişme ile sonuçlandığı gösterilmiştir [21].

Sporadik ALS'li hastaların nöronal inklüzyonlarındaki nörofilamentler ile bir ara filament olan periferin'in ilişkili olduğu öne sürülmüştür. Transgenik farelerde periferin aşırı ekspresyonunun, motor aksonların dejenerasyonu ile ilişkili olduğu ve inflamatuar sitokinlerin, periferin seviyelerini arttırdığı gösterilmiştir. Bu bulgu, periferin ile etkileşim yoluyla inflamasyon ve ALS arasında bağlantı olduğunu ileri sürmektedir [22].

Aksonal transportun inhibisyonu da, motor nöron dejenerasyonunun bir sebebi olabilir. Dynactin/dynein kompleksi mikrotubullerin gövdeye yakın negatif ucuna doğru taşıma yapar. Dynactin mutasyonlarının fare modellerinde motor nöron hastalığına yol açabildiği bildirilmiştir [23].

\section{Nöroinflamasyon ve gliaların rolü}

Astrositler salgıladıkları BDNF, GDNF, CNTF, VEGF gibi faktörler aracılığı ile nöronlar üzerine trofik etki gösterirler. Ayrıca EAAT-2 ve nöronal GluR2 subünit düzeyini etkileyerek nöronal differansiasyonu tetiklerler. ALS'de oligodendrosit prekürsörlerinin farklılaşması bozulur ve aksonal destek azalır. Mikroglialar MSS'nin immunmodulatör hücreleridir. Mikroglia hücreleri bir kez aktive edildiklerinde, nitrik oksit, oksijen radikalleri, sitokinler ve glutamatın da dahil olduğu, motor nöron hücresinin ölümüne yol açan diğer faktörleri de içeren bir dizi yolağı tetiklerler. Birçok çalışma, inflamatuar süreçlerin ALS hastalığı progresyonunda ve nöronal ölümde etkili olduğunu göstermiştir. Ve çalışmalar, mikroglial aktivasyonun mutant SOD1 proteini yada C9ORF72 mutasyonu tarafından tetiklendiğini ve nörodejenerasyona sebep olduğunu göstermektedir [24].

\section{RNA bozuklukları}

Son dönemdeki çalışmalar, bozulmuş RNA işleme ve anormal protein agregatlarının, ALS patogenezinde major bir rol oynadığını göstermektedir. TDP43 ve FUS mutasyonlarında çekirdekte RNA transkripsiyonunun splicing aşamaları etkilenmekte, sitoplazmaya yer değiştirme ile sitoplazmik agragatlar oluşmakta ve bunlar stres granüllerini etkilemektedir. Ayrıca burada translasyon ve transport basamakları da etkilenmektedir [25].

C9ORF72 mutasyonları sonucu çekirdekte RNA foci oluşmakta ve biyogenez splicing etkilenmektedir. Sitoplazmada dipeptid tekrar (DPR) aggregatları oluşmakta ve çekirdeğe protein import-exportu da etkilenmektedir [26].

\section{Otofaji yolaklarındaki disfonksiyon}

Nöronlar, çoğu hücre tipi gibi, hücresel homeostazı koruyan yapısal otofaji aktivitesi sergilerler [27, 28]. Motor nöronlar son derece özelleşmiş nöron çeşitleridirler ve ALS patolojisinde en fazla etkilenen hücre tipi olarak görülmektedirler [29]. Kaslara projekte olan uzun aksonlarıyla en elonge olmuş ve polarize memeli hücreleridirler. Sıradışı morfolojilerinin yanında, motor nöronların rejenere olma yetenekleri oldukça düşüktür ve mitotik aktivite göstermezler. Ki bu durum, yanlış katlanmış proteinler veya hasarlı mitokondri gibi işlevsiz hale gelen hücresel bileşenleri uzaklaştırarak hücresel homeostazı sağlamak ve hücre ölümünü önlemek için oldukça önemlidir [30, 31].

Nöronal otofaji, kararlı durum koşullarında koruyucu bir işleve sahiptir. Farelerde, santral sinir sisteminde otofaji için gerekli olan Atg5 ve Atg7 gibi genlerin kaybının, ubikuitinden zengin sitoplazmik inklüzyonların yaygın birikimi ile karakterize bir nerodejenerasyona yol açtığı gösterilmiştir [32, 33]. Otofajinin ALS patofizyolojisinde rol oynadığının en önemli bulgularından biri, ALS hastalarının spinal kord nöronlarının sitoplazmasında otofagozom birikimlerinin gösterilmesidir [34].

ALS'nin bugüne kadarki patofizyolojik mekanizmlarına dair çoğu anlayış, hastalığın hayvan modellerinin incelenmesi ile elde edilmiştir. Bunlar arasında, mutant SOD1 fare modelleri üzerinde durulmuş ve bu konuda 
çok sayıda çalışma yapılmıştır [35-39]. Murin mutant SOD1 modellerinde, mTOR aktivitesinde azalmaya ek olarak, Atg8-homologlarının görselleştirilmesi yoluyla otofagozom oluşumunda artış olduğu gösterilmiştir [40-42]. SOD1G93A fare modelinde, otofagozomlardaki artışla eş zamanlı olarak, p62 (otofaji reseptörünün komponenti) düzeylerinde de bir artış genellikle gözlenmiştir [43, 44]. Ayrıca, transkripsiyonel faktör TFEB'de (otofajik ve lizozomal biyogenez genlerinin ekspresyonunun düzenleyicisi) ve otofagozom maturasyonunda görev alan Beclin1'de de bir artış gözlenmiştir [45].

Genel olarak bakıldığında, bu parametreler otofajik yolakların aktivasyonuna işaret etmektedir. Ancak, bu aktivite, ALS hastalığının seyri sırasında lizozomal aktivitenin giderek artan yetersizliğine bağlı olarak protein agregatları ve hasarlı mitokondriler dahil ALS'de görülen işlevsiz hale gelmiş hücresel bileşenlerin uzaklaştırılmasında ve otofaji-kargolarının degredasyonunda yetersiz kalmaktadır $[44,46]$.

Bu mekanizmaların hiçbiri ALS patogenezini tek başına aydınlatamamaktadır. Dolayısıyla bunların ve daha birçok mekanizmanın birlikte ya da sebep sonuç ilişkisi içerisinde farklı kombinasyonlar halinde patogenezde rol oynadığı düşünülebilir. Net olan tek şey sonuçta aksonal kaybın meydana geldiği ve hastalığın bir merkezden başlayarak çevreye yayılım gösterdiğidir. Bu prion benzeri bir yayılım paterni açısından dikkat çekicidir. TDP-43 ve FUS gibi proteinler, agregasyona yatkınlık yaratan prion benzeri alanlara sahiptirler. Normalde, stres yanıtı olarak RNA'dan, protein sentezini düzenlemeye yardımcı olan geçici yapılar olan stres granüllerinin sentezlenmesinde işlev görürler. Bu proteinlerin prion benzeri alanlarındaki mutasyonlar, proteinlerin degradasyona dirençli olan stres granüllerine dönüşümünü arttırabilir ve devamında anormal RNA bağlayıcı proteinlerin self-agregasyonuna yol açabilir. Bunun sonucunda da sitoplazmik inklüzyonlar ortaya çıkar.

Sonuç olarak, genetik ve çevresel risk faktörlerine sahip, karmaşık ve çok faktörlü bir hastalık olan ALS'nin patogenezi şu an için tam olarak aydınlatılabilmiş değildir.
Hastalığın patogenezini daha iyi anlamak ve daha etkili tedavilere geçmek için ALS ile ilgili sorulara multidisipliner bütünsel bir yaklaşım gerekmektedir.

Çıkar ilişkisi: Yazarlar çıkar ilişkisi olmadığını beyan eder.

\section{Kaynaklar}

1. Byrne S, Walsh C, Lynch C, et al. Rate of familial amyotrophic lateral sclerosis: a systematic review and meta-analysis. J Neurol Neurosurg Psychiatry 2011;82:623-627. https://doi.org/10.1136/ jnnp.2010.224501

2. Rosen DR, Siddique T, Patterson D, et al. Mutations in $\mathrm{Cu} / \mathrm{Zn}$ superoxide dismutase gene are associated with familial amyotrophic lateral sclerosis. Nature 1993;362:59-62. https://doi.org/10.1038/362059a0

3. Reaume AG, Elliott JL, Hoffman EK, et al. Motor neurons in $\mathrm{Cu} / \mathrm{Zn}$ superoxide dismutase-deficient mice develop normally but exhibit enhanced cell death after axonal injury. Nat Genet 1996;13:43-47. https://doi. org/10.1038/ng0596-43

4. Gurney ME. Transgenic animal models of familial amyotrophic lateral sclerosis. J Neurol 1997;244:1520. https://doi.org/10.1007/bf03160575

5. Boillee S, Cleveland DW. Revisiting oxidative damage in ALS: microglia, Nox, and mutant SOD1. J Clin Invest 2008;118:474-478. https://doi.org/10.1172/JCI34613

6. Durham HD, Roy J, Dong L, Figlewicz DA. Aggregation of mutant $\mathrm{Cu} / \mathrm{Zn}$ superoxide dismutase proteins in a culture model of ALS. J Neuropathol Exp Neurol 1997;56:523-530. https://doi.org/10.1097/00005072199705000-00008

7. Zou ZY, Zhou ZR, Che CH, Liu CY, He RL, Huang HP. Genetic epidemiology of amyotrophic lateral sclerosis: a systematic review and meta-analysis. J Neurol Neurosurg Psychiatry 2017;88:540-549. https://doi. org/10.1136/jnnp-2016-315018

8. DeJesus-Hernandez M, Mackenzie IR, Boeve BF, et al. Expanded GGGGCC hexanucleotide repeat in noncoding region of C9ORF72 causes chromosome 9p-linked FTD and ALS. Neuron 2011;72:245-256. https://doi.org/10.1016/j.neuron.2011.09.011

9. Haeusler AR, Donnelly CJ, Periz G, et al. C9orf72 nucleotide repeat structures initiate molecular cascades of disease. Nature 2014;507:195-200. https://doi.org/10.1038/nature13124

10. Zhang K, Donnelly CJ, Haeusler AR, et al. The C9orf72 repeat expansion disrupts nucleocytoplasmic transport. Nature 2015;525:56-61. https://doi.org/10.1038/ nature14973 
11. Kwon I, Xiang S, Kato M, et al. Poly-dipeptides encoded by the C9orf72 repeats bind nucleoli, impede RNA biogenesis, and kill cells. Science 2014;345:11391145. https://doi.org/10.1126/science.1254917

12. Waite AJ, Baumer D, East S, et al. Reduced C9orf72 protein levels in frontal cortex of amyotrophic lateral sclerosis and frontotemporal degeneration brain with the C9ORF72 hexanucleotide repeat expansion. Neurobiol Aging 2014;35:1779.e5-1779.e13. https:// doi.org/10.1016/j.neurobiolaging.2014.01.016

13. Sreedharan J, Blair IP, Tripathi VB, et al. TDP-43 mutations in familial and sporadic amyotrophic lateral sclerosis. Science 2008;319:1668-1672. https://doi. org/10.1126/science. 1154584

14. Kwiatkowski TJJ, Bosco DA, Leclerc AL, et al. Mutations in the FUS/TLS gene on chromosome 16 cause familial amyotrophic lateral sclerosis. Science 2009;323:12051208. https://doi.org/10.1126/science.1166066

15. Calkins MJ, Johnson DA, Townsend JA, et al. The Nrf2/ARE pathway as a potential therapeutic target in neurodegenerative disease. Antioxid Redox Signal 2009;11:497-508. https://doi.org/10.1089/ ars.2008.2242

16. Rothstein JD, Tsai G, Kuncl RW, et al. Abnormal excitatory amino acid metabolism in amyotrophic lateral sclerosis. Ann Neurol 1990;28:18-25. https://doi. org/10.1002/ana.410280106

17. Kawahara $\mathrm{Y}$, Ito $\mathrm{K}$, Sun $\mathrm{H}$, Aizawa $\mathrm{H}$, Kanazawa I, Kwak S. Glutamate receptors: RNA editing and death of motor neurons. Nature 2004;427:801. https://doi. org/10.1038/427801a

18. Tadic V, Prell T, Lautenschlaeger J, Grosskreutz J. The ER mitochondria calcium cycle and ER stress response as therapeutic targets in amyotrophic lateral sclerosis. Front Cell Neurosci 2014;30:147. https://doi. org/10.3389/fncel.2014.00147

19. Liu J, Lillo C, Jonsson PA, et al. Toxicity of familial ALSlinked SOD1 mutants from selective recruitment to spinal mitochondria. Neuron 2004;43:5-17. https://doi. org/10.1016/j.neuron.2004.06.016

20. Kepp KP. Genotype-property patient-phenotype relations suggest that proteome exhaustion can cause amyotrophic lateral sclerosis. PLoS One 2015;10:e0118649. https://doi.org/10.1371/journal. pone.0118649

21. Mizusawa H, Matsumoto S, Yen SH, Hirano A, RojasCorona RR, Donnenfeld $H$. Focal accumulation of phosphorylated neurofilaments within anterior horn cell in familial amyotrophic lateral sclerosis. Acta Neuropathol 1989;79:37-43. https://doi.org/10.1007/ bf00308955
22. Sterneck E, Kaplan DR, Johnson PF. Interleukin-6 induces expression of peripherin and cooperates with Trk receptor signaling to promote neuronal differentiation in PC12 cells. J Neurochem 1996;67:1365-1374. https://doi.org/10.1046/j.14714159.1996.67041365.x

23. Munch $\mathrm{C}$, Sedlmeier R, Meyer T, et al. Point mutations of the p150 subunit of dynactin (DCTN1) gene in ALS. Neurology 2004;63:724-726. https://doi. org/10.1212/01.wnl.0000134608.83927.b1

24. Geloso MC, Corvino V, Marchese E, et al. The dual role of microglia in ALS: mechanisms and therapeutic approaches. Front Aging Neurosci 2017;25:242. https://doi.org/10.3389/fnagi.2017.00242

25. Ito $D$, Suzuki N. Conjoint pathologic cascades mediated by ALS/FTLD-U linked RNA-binding proteins TDP-43 and FUS. Neurology 2011;77:1636-1643. https://doi. org/10.1212/WNL.0b013e3182343365

26. Zhou Q, Lehmer C, Michaelsen M, et al. Antibodies inhibit transmission and aggregation of C9orf72 poly- GA dipeptide repeat proteins. EMBO Mol Med 2017;9:687702. https://doi.org/10.15252/emmm.201607054

27. Son JH, Shim JH, Kim KH, Ha JY, Han JY. Neuronal autophagy and neurodegenerative diseases. Exp Mol Med 2012;44:89-98. https://doi.org/10.3858/ emm.2012.44.2.031

28. Benito-Cuesta I, Diez H, Ordonez L, Wandosell F. Assessment of autophagy in neurons and brain tissue. Cells 2017;6:25. https://doi.org/10.3390/cells6030025

29. Valenzuela $V$, Nassif $M$, Hetz C. Unraveling the role of motoneuron autophagy in ALS. Autophagy 2018;14:733-737. https://dx.doi.org/10.1080\% 2F15548627.2018.1432327

30. Ciechanover A, Kwon YT. Degradation of misfolded proteins in neurodegenerative diseases: therapeutic targets and strategies. Exp Mol Med 2015;47:147. https://doi.org/10.1038/emm.2014.117

31. Kanning KC, Kaplan A, Henderson CE. Motor neuron diversity in development and disease. Annu Rev Neurosci 2010;33:409-440. https://doi.org/10.1146/ annurev.neuro.051508.135722

32. Komatsu M, Waguri S, Chiba $T$, et al. Loss of autophagy in the central nervous system causes neurodegeneration in mice. Nature 2006;441:880-884. https://doi.org/10.1038/nature04723

33. HaraT, NakamuraK, Matsui M, etal. Suppressionofbasal autophagy in neural cells causes neurodegenerative disease in mice. Nature 2006;441:885-889. https://doi. org/10.1038/nature04724

34. Sasaki S. Autophagy in spinal cord motor neurons in sporadic amyotrophic lateral sclerosis. J Neuropathol Exp Neurol 2011;70:349-359. https://doi.org/10.1097/ NEN.0b013e3182160690 
35. Beltran S, Nassif M, Vicencio E, et al. Network approach identifies pacer as an autophagy protein involved in ALS pathogenesis. Mol Neurodegener 2019;14:14. https://doi.org/10.1186/s13024-019-0313-9

36. Rudnick ND, Griffey CJ, Guarnieri P, et al. Distinct roles for motor neuron autophagy early and late in the SOD1(G93A) mouse model of ALS. Proc Natl Acad Sci USA 2017;114:8294-8303. https://doi.org/10.1073/ pnas. 1704294114

37. Nassif $M$, Valenzuela $V$, Rojas-Rivera $D$, et al. Pathogenic role of BECN1/Beclin 1 in the development of amyotrophic lateral sclerosis. Autophagy 2014;10:1256-1271. https://dx.doi. org/10.4161\%2Fauto.28784

38. Mitsui S, Otomo A, Nozaki $M$, et al. Systemic overexpression of SQSTM1/p62 accelerates disease onset in a SOD1(H46R)-expressing ALS mouse model. Mol Brain 2018;11:30. https://doi.org/10.1186/s13041018-0373-8

39. Li J, Song M, Moh S, Kim H, Kim DH. Cytoplasmic restriction of mutated SOD1 impairs the DNA repair process in spinal cord neurons. Cells 2019;8:1502. https://doi.org/10.3390/cells8121502

40. Morimoto $N$, Nagai $M$, Ohta $Y$, et al. Increased autophagy in transgenic mice with a G93A mutant SOD1 gene. Brain Res 2007;1167:112-117. https://doi. org/10.1016/j.brainres.2007.06.045

41. Hetz C, Thielen P, Matus S, et al. XBP-1 deficiency in the nervous system protects against amyotrophic lateral sclerosis by increasing autophagy. Genes Dev 2009;23:2294-2306. https://doi.org/10.1101/ gad.1830709

42. Saxena S, Roselli F, Singh K, et al. Neuroprotection through excitability and $\mathrm{mTOR}$ required in ALS motorneurons to delay disease and extend survival. Neuron 2013;80:80-96. https://doi.org/10.1016/j. neuron.2013.07.027

43. Gal J, Strom AL, Kilty R, Zhang F, Zhu H. p62 accumulates and enhances aggregate formation in model systems of familial amyotrophic lateral sclerosis. J Biol Chem 2007;282:11068-11077. https://doi. org/10.1074/jbc.M608787200

44. An T, Shi P, Duan W, et al. Oxidative stress and autophagic alteration in brainstem of SOD1-G93A mouse model of ALS. Mol Neurobiol 2014;49:14351448. https://doi.org/10.1007/s12035-013-8623-3

45. Settembre C, Ballabio A. TFEB regulates autophagy: an integrated coordination of cellular degradation and recycling processes. Autophagy 2011;7:1379-1381. https://doi.org/10.4161/auto.7.11.17166

46. Xie Y, Zhou B, Lin MY, Wang S, Foust KD, Sheng $\mathrm{ZH}$. Endolysosomal deficits augment mitochondria pathology in spinal motor neurons of asymptomatic fALS mice. Neuron 2015;87:355-370. https://doi. org/10.1016/j.neuron.2015.06.026 